\title{
Enterprise Life Cycle and Earnings Management: A Study Based on Mediating Effect of Financing Demand
}

\author{
Hua YOU, Ying DU \\ Northwest University, Xi'an, China \\ $\{$ hy363, Echo2319\}@163.com
}

\begin{abstract}
With the data of listed companies in stock markets of Shanghai and Shenzhen from 2009 to 2015, this paper gives an empirical study of earnings management from the dynamic perspective of enterprise life cycle, analyses the impact of enterprise life-cycle stages on earnings management, and then explores the path mechanism that enterprise life cycle influences earnings management from the perspective of financing needs. The results show that enterprise life-cycle stages play an important impact on earnings management. The level of enterprise earnings management in growth and depression period is higher than that in maturity period. In addition, the larger the demand of corporate financing needs, the higher the level of enterprise earnings management, and financing demand is partly mediated in the impact of enterprise life cycle on enterprise earnings management. Therefore, we should further enhance the internal governance of companies, improve the external financial environment and expand the financing channels to restrain enterprise earnings management. What's more, the external investors, supervisors and auditors should pay more attention to the quality of accounting earnings information of enterprises in growth and depression period and reduce the noise of financial information.
\end{abstract}

Key words: Enterprise Life Cycle, Financing Needs, Earnings Management, Mediating Effect.

\section{Introduction}

As an ever-changing dynamic organization, an enterprise will go through different life cycle stages, such as creation, growth, maturity and decline. In each of life cycle stage, the enterprise has its own unique characteristics [10]. For example, the enterprise internal business activities, investment and financing activities, ownership structure and corporate governance and external competition are quite different in different life cycle stages. Therefore, it is necessary to study enterprise earnings management behavior from the dynamic perspective of enterprise life cycle.

According to the theory of enterprise life cycle, enterprises in different life cycle stages have different organizational structure and financial strategy, and there are certain differences between their internal operation and external environment [1]. 
Therefore, enterprises in different life cycle stages have varying degrees of agency problems, so the motivation and ability of managers in different life cycles enterprises to manipulate earnings will be different. In addition, there are also great differences in corporate culture, management style and market competitiveness between different life cycle enterprise, so enterprises in different life cycle stages often have different levels of earnings management.

In view of this, this paper takes the data of A-share listed companies in Shanghai and Shenzhen stock exchanges from 2009 to 2015 as samples and makes an empirical study on earnings management behavior from the dynamic perspective of enterprise life cycle. The results show that the level of earnings management is significantly different between different life cycle stage. Specifically, compared with mature stage enterprises, growth stage and decline stage enterprises have a higher degree of earnings management, and decline stage enterprises have the highest level of earnings management, followed by growth stage enterprises. Furthermore, this paper discusses the path mechanism of the impact of enterprise life cycle on earnings management from the perspective of financing demand. The results show that financing demand partially mediates the impact of enterprise life cycle on earnings management.

\section{Literature Review and Hypothesis Development}

\subsection{Enterprise Life Cycle and Earnings Management}

Enterprises in growth period with more investment opportunities and faster expansion speed, so they always want to show good business performance to attract outside investors to meet financing needs, which will strengthen the manager's motivation for earnings management behavior. The operation activities of mature enterprises are relatively stable, with huge markets share and strong profitability, and can generate a large amount of cash flow to meet their own capital needs. Moreover, mature enterprise governance structure and internal control system are relatively more perfect. All of that will lead to a lower level of the enterprise earnings management in mature period. Enterprises in decline period generally accompanied by customer loss and market share reduction, and the company financial situation have deteriorated significantly. In order to obtain external funds to maintain development and avoid the supervision of securities market, showing good business performance is essential, therefore, management of these enterprises will improve performance through earnings management [3]. Moreover, the principal-agent problem of enterprises in the decline period is further highlighted, and managers may conduct more earnings management behavior out of self-interest motivation. Thus, we hypothesize:

H1: The life cycle of enterprise is an important factor to determine the level of earnings management. Compared with mature enterprises, growth and decline enterprises have a higher degree of earnings management. 


\subsection{Enterprise Life Cycle and Financing Demand}

The financing needs of enterprises in different life cycle are significantly different. Enterprises in growth period are faced with more development opportunities, however, most enterprises in growth period have not yet formed a stable profitability. The cash flow provided by their own is insufficient to support their external expansion needs. Therefore, enterprises in growth period usually have huge demand for external capital. Enterprises in mature period have relatively stable customer groups, large market share and strong profitability, which could produce sufficient cash flow to meet their capital need. Moreover, compared with growth period enterprise, the growth rate of enterprises in mature stage have slowed down, so their external financing nedds will be reduced. Enterprises in decline stage generally have terrible living conditions and development difficulties, And the cash flow generated by them is usually difficult to maintain the company normal and sustainable development, so they have a greater demand for external financing [2]. Formally stated, we hypothesize:

$\mathrm{H} 2$ : The life cycle of enterprise is an important factor in determining it's financing needs. Compared with mature enterprises, growth and decline enterprises have greater financing demand.

\subsection{Corporate Financing Needs and Earnings Management}

Many scholars have found that accounting information is an important base for equity investors and creditors to sign contracts with enterprises [9]. Therefore, the accounting information will be more probably managed to some extent when there is financing demand [11]. The debt contract hypothesis holds that creditors understand the financial situation of an enterprise based on its financial statements inducing managerial motivation for earnings management. Because the better operating performance reflected by accounting information, the creditors will provide them with loans of larger amount and lower cost. Under such circumstances, it is a common phenomenon for managers to whitewash their statements in order to meet the harsh conditions of bank loans [12,5]. Moreover, many scholars have found that in the process of equity financing, earnings management can also be carried out to a certain degree [4]. Thus, we hypothesize:

H3: The financing demand of enterprises will have an impact on earnings management, and the higher the financing demand, the higher the level of earnings management.

H4: Financing demand partially mediates the impact of enterprise life cycle on earnings management. 


\section{$3 \quad$ Research Design}

\subsection{Model Design}

We use model (1) to test the impact of enterprise life cycle on earnings management:

$$
\begin{aligned}
& D A=\alpha_{0}+\alpha_{1} G P 1+\alpha_{2} G P 3+\alpha_{3} \text { Size }+\alpha_{4} \text { Debt }+\alpha_{5} \text { Roe }+\alpha_{6} \text { Tar } \\
& +\alpha_{7} \text { Audit }+\alpha_{8} M c+\alpha_{9} C_{-} 10+\varepsilon
\end{aligned}
$$

We construct model (2) to test the impact of enterprise life cycle on financing demand: $P(F n=1)=\frac{1}{1+e^{-\left(\beta_{0}+\beta_{1} G P 1+\beta_{2} G P 2+\beta_{3} \text { Size }+\beta_{4} \text { Debt }+\beta_{5} \text { Roe }+\beta_{6} \text { Tar }+\beta_{7} F l+\beta_{8} C r \_10\right)}} \quad 2$

We use model (3) to examine the impact of financing demand on earnings management:

$D A=\gamma_{0}+\gamma_{1} F n+\gamma_{2} G p 1+\gamma_{3} G P 3+\gamma_{4}$ Size $+\gamma_{5} D e b t+\gamma_{6} R o e$

$+\gamma_{7} \mathrm{Tar}+\gamma_{8}$ Audit $+\gamma_{9} \mathrm{Mc}+\gamma_{10} \mathrm{Cr} r_{-} 10+\varepsilon$

Among them, $D A$ represents earnings management. Independent variables include growth period (GP1), maturity period $(G P 2)$ and decline period (GP3). Mediator variable is financing demand $P(F n=1)$. The control variables include Size, Debt, ROE, Tar, Fl, Audit, $\mathrm{Mc}$, and $\mathrm{Cr}_{-} 10$.

\subsection{Key Variable Measure}

Enterprise Life Cycle. This paper divides the enterprise life cycle according to the research by Dickinson [6], which has been adopted by many scholars. The life cycle divided results are reported in table 1 .

Table 1. Enterprise life cycle divided results.

\begin{tabular}{llllllll}
\hline Growth & Growth & & Decline & Decline & Decline & Decline & Decline \\
Period & Period & Mature & Period & Period & Period & Period & Period \\
1 & 2 & Period & & 2 & 3 & 4 & 5 \\
\hline
\end{tabular}

Net Cash

Flow from 
Operation

Net Cash

Flow from

Investment

Net Cash

Flow from

Financing

Financing Demand. The method used to measure financing demand is proposed by Demirguc-Kunt and Maksimovic [7]. This model capture the financing demand through the difference between total assets real growth rate and sustainable growth rate. The formula is as follows:

$$
F n=\left(A_{t}-A_{t-1}\right) / A_{t-1}-\operatorname{Roe}_{t} /\left(1-\operatorname{Roe}_{t}\right)
$$

$A$ represents total assets of the company, and Roe represents the return on equity. $F n$ is used as the proxy for financing demand, when the $F n$ value is greater than the industry's annual average, then which will be assigned to 1, indicating that the company's financing demand is larger. Otherwise $F n$ will be assigned to 0 , indicating that the company's financing demand is smaller.

Earnings Management. Based on the cross-sectional modified Jones model [8], this paper calculates the accrued earnings management by year and by industry regression to represent the degree of enterprise earnings management.

\subsection{Sample Selection and Data Sources}

We take the financial data of A-share listed companies in Shanghai and Shenzhen stock exchanges from 2009 to 2015 as the research sample. All the data come from CCER database. Referring to previous studies, the following steps were carried out to samples:

1. We eliminate financial and insurance industry companies, companies with incomplete research data, and ST, PT companies.

2. We winsorize the extreme $1 \%$ of the distribution of acquisition activity variables to reduce the effects of extreme observations.

3 . Because the previous period of data is needed to calculate the accrued earnings management, the regression analysis of this paper finally uses 11963 valid samples between 2010-2015, using Stata12 to process data. Variable definitions and instructions are detailed in Table 2. 
Table 2. Variable definitions and instructions.

\begin{tabular}{|c|c|c|}
\hline Variable Name & $\begin{array}{l}\text { Variable } \\
\text { Symbol }\end{array}$ & Variable Description \\
\hline $\begin{array}{l}\text { Earnings } \\
\text { Management }\end{array}$ & $D A$ & $\begin{array}{l}\text { Calculate according to the cross-sectional modified Jones model, } \\
\text { then take absolute value to represent enterprise earnings } \\
\text { management }\end{array}$ \\
\hline $\begin{array}{l}\text { Financing Demand } \\
\text { Probability }\end{array}$ & $P(F n=1)$ & The larger probability of corporate financing demand \\
\hline Growth Period & $G P 1$ & $\begin{array}{l}\text { The GPl equals one if the enterprise in growth period, otherwise } \\
\text { is } 0\end{array}$ \\
\hline Mature Period & $G P 2$ & $\begin{array}{l}\text { The } G P 2 \text { equals one if the enterprise in mature period, otherwise } \\
\text { is } 0\end{array}$ \\
\hline Decline Period & $G P 3$ & $\begin{array}{l}\text { The } G P 3 \text { equals one if the enterprise in decline period, otherwise } \\
\text { is } 0\end{array}$ \\
\hline Financing Demand & $F n$ & $\begin{array}{l}\text { The } F n \text { equals one if the enterprise with larger financing needs, } \\
\text { otherwise is } 0\end{array}$ \\
\hline Company Size & Size & The total assets of the company are taken logarithm \\
\hline Asset Liability Ratio & Debt & Ratio of total liabilities to total assets \\
\hline Return on Net Assets & Roe & Ratio of net profit to shareholders' equity \\
\hline Turnover of Total & Tar & Ratio of operating income to total assets \\
\hline Assets & & \\
\hline Financial Leverage & $\mathrm{Fl}$ & Ratio of total liabilities to shareholders' equity \\
\hline
\end{tabular}




$\begin{array}{lll}\begin{array}{l}\text { Establishment of } \\ \text { Audit committee }\end{array} & \begin{array}{l}\text { The dummy variable, the enterprise with an audit committee } \\ \text { assigns to } 1 \text {, otherwise is } 0\end{array} \\ \text { Executive Monetary } & \text { The total amount of the top three executives payments are taken } \\ \text { Compensation } & \text { logarithmic } \\ \text { The Top Ten Majority } & C_{-} 10 & \text { Shares held by the top ten shareholders } \\ \text { Shareholding Ratio } & \end{array}$

\section{$4 \quad$ Empirical Results}

\subsection{Single Factor Analysis}

In this paper, the mean test (independent sample T test) and the median test (rank sum test) are used to test whether there are significant differences of enterprise earnings management in different life cycle stages. According to Table 3, whether the mean test ( $\mathrm{T}$ values are 15.0515 and 20.7615 , significant at the $1 \%$ level) or the median test ( $\mathrm{Z}$ values are 13.338 and 20.488 , significant at the $1 \%$ level), shows that there are significant differences in the degree of earnings management between enterprises in different life cycle stages. Moreover, the level of earnings management of enterprises in growth and decline periods is higher than that of mature enterprises, indicating that the second half of hypothesis 1 is verified.

Table 3. Single factor analysis of enterprise earnings management level in different life cycle.

\begin{tabular}{lllllll}
\hline & \multicolumn{2}{c}{ The Mean Test } & \multicolumn{3}{c}{ The Median Test } \\
Growth & Growth & Mature & T value & Growth & Mature & Z value \\
period - & period & period & & period & period & \\
Mature & $D A$-mean & $D A$-mean & & $D A$-median & $D A$-median & \\
period & 0.0893 & 0.0649 & $15.0515^{* * *}$ & 0.0632 & 0.0484 & $13.338^{* * *}$ \\
Decline & Decline & Mature & T value & Decline & Mature & Z value \\
period - & $D A$-mean & period & & period & period & \\
Mature & & DA-mean & & DA-median & $D A$-median & \\
\hline
\end{tabular}




\begin{tabular}{lllllll}
\hline period & 0.1061 & 0.0649 & $20.7615^{* * *}$ & 0.0838 & 0.0484 & $20.488^{* * *}$ \\
\hline
\end{tabular}

Notes: Data is calculated by Stata12.0.

***,**, * significant respectively at 1 percent, 5 percent, 10 percent level.

In addition, the mean test (independent sample $\mathrm{T}$ test) and the median test (rank sum test) are used to verify whether there are significant differences in the financing demand of enterprises in different life cycles. According to Table 4, whether the mean test ( $\mathrm{T}$ value is 57.2297 and 10.5158, significant at the $1 \%$ level) or the median test ( $\mathrm{Z}$ value is 49.633 and 10.424 , significant at the $1 \%$ level), shows that there is a significant difference in the degree of financing demand between enterprises in different life cycle stages. And compared with mature enterprises, the degree of financing needs of enterprises in growth and decline periods is higher than that of mature enterprises, indicating that the second half of hypothesis 2 is verified.

Table 4. Single factor analysis of enterprise financing demand degree in different life cycle.

\begin{tabular}{lllllll}
\hline & \multicolumn{2}{c}{ The Mean test } & \multicolumn{3}{c}{ The Median Test } \\
Growth- & Growth & Mature & T value & Growth & Mature & Z value \\
Mature & period & period & & period & period & \\
period & Fn-mean & Fn-mean & & Fn-median & Fn-median & \\
& 0.6026 & 0.1088 & $57.2297^{* * *}$ & 1 & 0 & 49.633*** \\
& Decline & Mature & T value & Decline & Mature & Z value \\
Decline - & period & period & & period & period & \\
Mature & Fn-mean & Fn-mean & & Fn-median & Fn-median & \\
period & 0.2072 & 0.1088 & $10.5158^{* * * *}$ & 0 & 0 & $10.424 * * *$ \\
\hline
\end{tabular}

Notes:Data is calculated by Stata12.0.

***,**, * significant respectively at 1 percent, 5 percent, 10 percent level.

\subsection{Regression Results Analysis}

In this paper, models (1) and models (3) are regressed by ordinary least square method and the regression results of models (1) and models (3) are shown in Table 5. we can see that the positive effects of growth period and decline period on enterprise earnings management have passed $1 \%$ significant test, and the empirical results support the hypothesis 1 . The regression results of model (3) show that the positive impact of 
corporate financing demand on earnings management has passed $1 \%$ significant test. This result shows that the greater the demand for external funds, the higher the level of management earnings will be, which indicate the hypothesis 3 is verified. From other control variables, in the regression results of model (1) and model (3), the negative impact of enterprise assets scale on earnings management have all passed the $1 \%$ significance level test, which shows that the larger the scale of enterprises is, the lower the degree of earnings management, because the internal governance structure of larger enterprises is relatively perfect. The top ten shareholders equity ratio has a positive impact on earnings management, and has passed the $1 \%$ significance test, indicating that relatively decentralized ownership structure is conducive to restraining earnings management.

In this paper, model (2) is used logit regression. From table 5, we can see that both the growth period enterprises and the decline enterprises are positively related to the financing demand, and have passed the $1 \%$ significance level test, which shows that compared with the mature enterprises, the financing demand of the growth period enterprises and the decline enterprises is much larger. Hypothesis 2 has got the empirical results support. There is a negative correlation between the size of enterprises and the financing demand at a significant level of $1 \%$, which indicates that compared with large enterprises, small enterprises need more external capital. These empirical results also indicate that the government should introduce more policies to broaden the financing channels for small enterprises. According to table 5, enterprise life cycle has a significant impact on earnings management. At the same time, the impact of enterprise life cycle on financing demand and the impact of financing demand on earnings management are also significant. This shows that the path mechanism of enterprise life cycle influences the company's earnings management through financing demand does exist. In other words, financing demand partially mediates the impact of enterprise life cycle on earnings management. Hypothesis 4 has got empirical results support.

Table 5. Regression results of life cycle, financing demand and earnings management.

\begin{tabular}{|c|c|c|c|c|c|c|}
\hline & Model（1） & & Model (2) & & Model（3） & \\
\hline & Explanatory & & Explanatory & & Explanatory & \\
\hline Independe & variable & $\mathrm{T}$ value & variable & $Z$ value & variable & $\mathrm{T}$ value \\
\hline nt Variable & $D A$ & & $\mathrm{P}(\mathrm{Fn}=1)$ & & $D A$ & \\
\hline$G P 1$ & $0.0281 * * *$ & 24.35 & $2.4508 * * *$ & 41.22 & $0.0121 * * *$ & 6.83 \\
\hline GP3 & $0.0381 * * *$ & 17.68 & $0.6173 * * *$ & 7.78 & $0.0353 * * *$ & 16.68 \\
\hline$F n$ & & & & & $0.0350 * * *$ & 20.69 \\
\hline
\end{tabular}




\begin{tabular}{|c|c|c|c|c|c|c|}
\hline Size & $-0.0187 * * *$ & -23.53 & $-0.1641 * * *$ & -6.94 & $-0.0176^{* * *}$ & -22.47 \\
\hline Debt & $0.0161 * * *$ & 3.56 & $2.0670^{* * *}$ & 10.13 & 0.0018 & 0.40 \\
\hline Roe & 0.0015 & 0.50 & $-2.7438 * * *$ & -11.32 & $0.0075^{* *}$ & 2.52 \\
\hline Tar & $0.0162 * * *$ & 12.16 & $-0.2861 * * *$ & -5.71 & $0.0177 * * *$ & 13.48 \\
\hline Audit & 0.0001 & 0.06 & & & 0.0003 & 0.11 \\
\hline$M c$ & $-0.020 *$ & -1.71 & & & -0.0019 & -1.64 \\
\hline $\mathrm{Cr}_{-} \mathrm{IO}$ & $0.0682 * * *$ & 14.20 & $1.4343^{* * *}$ & 9.16 & $0.0606^{* * *}$ & 12.79 \\
\hline$F l$ & & & $0.0465^{*}$ & 1.77 & & \\
\hline _cons & $0.4436^{* * *}$ & 24.35 & 0.4744 & 0.95 & $0.4196^{* * *}$ & 23.39 \\
\hline Year & yes & & yes & & yes & \\
\hline Industry & yes & & yes & & yes & \\
\hline \multirow[t]{3}{*}{$\mathrm{N}$} & 11963 & & 11963 & & 11963 & \\
\hline & Adj- $R^{2}$ & & Pseudo $\mathrm{R}^{2}$ & & Adj- $R^{2}$ & \\
\hline & 0.1286 & & 0.2390 & & 0.1587 & \\
\hline F value & $57.94 * * *$ & & & & $71.52 * * *$ & \\
\hline
\end{tabular}

Notes: Data is calculated by Stata12.0.

***,**,* significant respectively at 1 percent, 5 percent, 10 percent level.

\section{Conclusion}

This paper studies the earnings management from the dynamic perspective of enterprise life cycle and explores the path mechanism of the impact of enterprise life cycle on earnings management from the view of financing demand. The results show that there are significant differences of earnings management in different life cycle, and growth and decline periods have a significant positive impact on the level of enterprise earnings management. Moreover, empirical results support that financing demand plays a mediation role in the impact of enterprise life cycle on earnings 
management. The results illustrate that compared with mature enterprises, enterprises in growth and decline periods have greater financing needs, and the greater demand of corporate financing, the higher level of earnings management. The result of this research not only provides empirical evidence for the effect of enterprise life cycle on earnings management, but also partly explains how the enterprise life cycle affects earnings management.

The research of this paper will not only help to enrich the study of earnings management behavior, but also can help the external stakeholders to better identify the earnings management behavior of enterprises and understand the real financial situation of the enterprises to some extent. The revelation of this study is as follows. Firstly, we should further perfect internal governance (such as improving management pay structure and internal control) to restrain earnings management activities and reduce financial information noise. Besides, external investors, regulators and auditors should pay more attention to the quality of accounting earnings information of enterprises in growth and decline periods. Secondly, we should further enhance the external financing environment, expanding financing channels, and building financing platform to solve the problem of financing difficulties.

\section{References}

1. Adizes, I.: How and Why Corporation Grow and Die and What to Do about It: Corporate Life Cycle. Prentice-Hall Publisher, New Jersey (1990).

2. N. Berger, A., F. Udell, G.: The Economics of Small Business Finance: The Roles of Private Equity and Debt Markets in the Financial Growth Cycle. Journal of banking and finance 22(6-8), 613-673 (1998), DOI:10.1016/s0378-4266(98)00038-7.

3. Burgstahler, D. C., Eames, M. J.: Earnings Management to Avoid Losses and Earnings Decreases: Are Analysts Fooled? Contemporary accounting research 20(2), 253-294 (2003), DOI: 10.1506/bxxp-rgtd-h0pm-9xal.

4. Cohen, D. A., Zarowin, P.: Accrual-based and Real Earnings Management Activities Around Seasoned Equity Offerings. Journal of accounting and economics 50(1), 2-19 (2010), DOI:10.1016/j.jacceco.2010.01.002.

5. Diana, R., Hassan, R., Gerald, J.: Impact of Proximity to Debt Covenant Violation on Earnings Management. Review of accounting studies 19(1), 473-505 (2014), DOI: 10.1007/s11142-013-9252-9.

6. Dickinson, V.: Cash Flow Patterns as a Proxy for Firm Life Cycle. The accounting review 86(6), 1969-1994 (2011), DOI: 10.2308/accr-10130.

7. Demirguc-kunt, A., Maksimovic, V.: Law, Finance and Firm Growth. The journal of finance 53(6), 2107-2173 (1998). DOI: 10.1111/0022-1082.00084.

8. Jones, J. J.: Earnings Management During Import Relief Investigations. Journal of accounting research 29(2), 193-228 (1991), DOI: 10.2307/2491047.

9. Leftwich, R.: Accounting Information in Private Markets: Evidence from Private Lending Agreements. The accounting review 58(1), 23-42 (1983).

10. Miller, D., Friesen P.: A Longitudinal Study of the Corporate Life Cycle. Management science 30(10), 1161-1183 (1984), DOI: 10.1287/mnsc.30.10.1161. 
11. Nopphon, T.: The Role of Corporate Governance in Reducing the Negative Effect of Earnings Management. International journal of economics and finance 5(3), 213-220 (2013), DOI: 10.5539/ijef.v5n3p213.

12. Valipour, H., Moradbeygi, M.: Corporate Debt Financing and Earning Quality. Journal of applied finance and banking 1(3): 139-157(2011), DOI: 10.1111/j.14685957.2010.02194.x. 